\title{
Miguel de Unamuno and John Dewey: the system of education and personal liberty ${ }^{1}$
}

\author{
Vladimer Luarsabishvili \\ https://orcid.org/0000-0001-9510-5080
}

This study offers an interpretation of Miguel de Unamuno's and John Dewey's views on education. The article consists of three parts. After the short introduction which describes Unamuno's and Dewey's general views on education and their impact on the development of the system of education in different countries, in the first part of the article I describe Unamuno's approach to education in general and the role of pedagogy in particular; in the second part the education is interpreted based on Dewey's point of view; and the third part represents the analysis of similarities in the understanding of the role of education and its place in the formation of personal liberty. This is the first attempt to connect Unamuno's and Dewey's views on this topic.

Keywords: Miguel de Unamuno, John Dewey, education, personal liberty

VLADIMER LUARSABISHVILI, PhD, Group of investigation CPyR (Autonomous University of Madrid), professor in Politics and International Relations at New Vision University, Tbilisi; address for correspondence: New Vision University, 1a Evgeni Mikeladze St., 0159, Tbilisi, Georgia; e-mail: vluarsabishvili@newvision.ge

${ }^{1}$ This article is a result of the research carried out within the RDI project "Analogy, equivalence, polyvalence and transferability as cultural-rhetoric and interdiscursive foundations of the art of language: literature, rhetoric and discourse" (Acronym: TRANSLATIO. Reference: PGC2018-093852-B-I00), funded by the Spanish Ministry of Science, Innovation and Universities. 
My paper is an attempt to link the main peculiarities of Miguel de Unamuno's and John Dewey's thoughts on the system of education. ${ }^{1}$ In particular, I tried to pay attention to the role of education in the formation of personal liberty. The education is a topic widely studied by both authors. The vast bibliography on it in case of Unamuno may be divided into three parts: first, reflecting the social and educational thoughts of the author; ${ }^{2}$ second, describing the ideas of Unamuno concerning the education in general ${ }^{3}$, and third, presenting Unamuno as an intellectual related to the university. ${ }^{4}$ This division of critical bibliography seems logic as Unamuno was broadly publishing on the three mentioned topics. ${ }^{5}$

${ }^{1}$ The present paper deals with some key concepts presented at the international conference "El pensamiento filosófico-social en España y America Latina", organized at the faculty of philosophy at Marie Curie-Skłodowska University, on September 13-14, 2018 and dedicated to the memory of Professor Eugeniusz Górski. This was the second part of the new academic tradition established on May 15-16, 2014. The conference gathered various scientists from different parts of the world, including Germany, Denmark, Spain, Chile, México and Georgia.

${ }^{2}$ César Aguillera Herrero Castro, "Pensamiento social-educativo de Miguel de Unamuno: estructura y cambio social en la España del primer tercio del siglo XX,“ Studia Paedagogia 22, no. 22 (1991): 55-79; Cirico Morón Arroyo, Hacia el sistema de Unamuno: estudios sobre su pensamiento y creación literaria. Plasencia: Calamo, 2003; Gemma Gordo Piñar, "El pensamiento educativo de Miguel de Unamuno," Humanistyka i Przyrodoznawstwo, no. 18 (2012): 167-182.

${ }^{3}$ Cesar Aguilera Aguilera, "Pensamiento educacional de D. Miguel de Unamuno," Calasencia 11, no. 44 (1965): 405-523; Criado Buonaventura Delgado, Unamuno educador (Madrid: Editorial Magisterio Español, 1973); Maria Gómez Molleda, "Unamuno y la polémica sobre la autonomía universitaria," in AA. VV. Perspectivas de España Contemporánea. Estudios en homenaje al professor V. Palacios Atard (Madrid: Guthersa, 1986), 355-399; Rafael Rubio Latorre, Educación y educador en el pensamiento de Unamuno (Salamanca: Ediciones Instituto Pontífico San Pio X, 1974); José Manuel de Barros Dias, "Miguel de Unamuno: a teorização da educação contra a modernidade da Pedagogia," Broteria. Cultura e Informação 139, no. 2-3 (1994): 167-181; Francisco Blanco Prieto, Unamuno: professor y rector en la Universidad de Salamanca (Salamanca: Hergar Ediciones Antema, 2011).

${ }^{4}$ Manuel García Blanco, "Don Miguel y la Universidad," Cuadernos de la Cátedra Miguel de Unamuno, no. 13 (1963): 13-32; Gómez Molleda, "Unamuno y la polémica sobre la autonomía universitaria," Cuadernos de la Cátedra Miguel de Unamuno 1963, no. 13: 13-32.; Ignacio Berdugo Gómez de la Torre, "Unamuno y la Universidad: rector e intellectual," in C. Flórez Miguel (coord.), Tu mano es mi destino (Salamanca: Ediciones Universidad de Salamanca, 2000), 45-58; Joaquín Madruga Méndez, Miguel de Unamuno: profesor y politico (Salamanca: Gráficas Cervantes, 2007).

${ }^{5}$ As an example of the mentioned I can cite three publications of Unamuno: 1) "De la enseñanza superior en España" (1899), in Obras completas, tomo III (Madrid: Esceliser, 1970), 64; 2) "Discurso de Orense" (1903), 527, in Obras completas, tomo VII (Madrid: Esceliser, 1970), 527; 3) "La enseñanza 
In case of John Dewey the list is more numerous and diverse, as he was not only the prominent theorist of education but, at the same time, the philosopher. Based on the main focus of this investigation, I will limit myself with reviewing his ideas related to education. From this point of view, I would divide the articles investigating Dewey's educational ideas into three groups: a) the contribution of Dewey to the development of different disciplines, ${ }^{6}$ b) the reception of Dewey's philosophy of education in different countries, ${ }^{7}$ and c) the confluences between Dewey and other philosophers. ${ }^{8}$ At the same time, I would also recommend the very informative bibliographical article of Paciano Fermoso Estébanez ${ }^{9}$ which

universitaria, presented at the II University Assembly, in Obras completas, tomo VII, 619.

6 Miguel Ángel Cadrecha Caparros, "John Dewey: propuesta de un modelo educativo: I. Fundamentos," Aula Abierta 1990, no. 55: 61-87; Miguel Catalán, “John Dewey: Los límites de la ética científica," Agora 1991, no. 13/1: 139-147; Miguel Catalán, "Una presentación de John Dewey," Daimon. Revista de Filosofía 2001, no. 22: 127-134; David Kennedy, "John Dewey on children, childhood, and education," Childhood \& Philosophy2, no. 4 (2006): 211-229; David González Hernández, "El público y sus problemas. John Dewey en los estudios de comunicación," Razón y Palabra 2011, no. 75: 1-14; Marcos Santos Gómez, "Limitaciones de la pedagogía de John Dewey," Bordón 2011, no. 63: 121-130; José María Rosales, "La retórica de la democracia y el liberalismo político en los escritos de John Dewey," Revista de Estudios Políticos 2012, no. 155: 185-206; Alexandre Sotelino Losada, “A aprendizaxe-servizo en perspectiva. John Dewey como referente histórico," Sarmiento 2015, no. 18-19: 145-162; C. Carreras Planas, "John Dewey i l'educaciy democratica," Educaciy i Historia: Revista d'Histrria de l'Educaciy 2015, no. 25: 21-42; Krzysztof Skowroński, "Entre política y estética: la idea de la democracia liberal en la filosofía del arte de John Dewey," La torre del Virrey, Revista de Estudios Culturales 19, no. 1 (2016): 1-11; Marta Vaamonde Gamo \& Jaime Nubiola, "El legado feminista de John Dewey," Espacio, Tiempo y Educación 2016, no. 3(2): 281-300; José Miguel Esteban Cloquell, "John Dewey y la tragedia de los communes," Éndoxa: Series Filosóficas 2017, no. 39: 265-284.

${ }^{7}$ Erika Natacha Fernandes de Andrade \& Marcus Vinicius da Cunha, "A contribuição de John Dewey ao ensino da arte no Brasil," Espacio, Tiempo y Educación 2016, no. 3(2): 301-319; Suzana Miovska-Spaseva, "The educational theory of John Dewey and its influence on educational policy and practice in Macedonia," Espacio, Tiempo y Educación, no. 3(2) (2016): 207-224; Yelena Rogacheva, "The Reception of John Dewey's Democratic Concept of School in Different Count ries of the World," Espacio, Tiempo y Educación, no. 3(2) (2016): 65-87; Imre Fenyö, "The Reception of John Dewey in Hungary," Espacio, Tiempo y Educación 2016, no. 3(2): 183-205.

${ }^{8}$ Richard Marc Rubin, “George Santayana and John Dewey meet," Limbo 2010, no. 30: 31-52; José Cláudio Matos, "John Dewey e Aldous Huxley: o admirável e o impensável na formação social da mentalidade," Conjectura Caxias do Sul 16, no. 3 (2011): 78-96. Marc Pallarès Piquer \& María Carmen Muñoz Escalada, "La vigencia de Hannah Arendt y John Dewey en la acción docente del siglo XXI," Foro de Educación 2017, no. 15(22): 1-23.

${ }^{9}$ Paciano Fermoso Estébanez, „Bibliografía sobre John Dewey: Filosofía de la Educación,” Teoría de la educación 1991, no. 3: 165-178; Vucina Zorić, “Influencia de John Dewey en las reformas educativas en Turquía y en la Unión soviética,” Espacio, Tiempo y Educación 2016, no. 3(2): 101-130; Taylor Xóchil, 
lists Dewey's main works dedicated to the questions of education. (In particular, Fermoso Estébanez divides Dewey's works on education into: a) principal philosophical works (general considerations), and b) pedagogical thought and philosophic-educational works.)

Education was a topic widely discussed in Europe during the second half of the XIX and the beginning of the XX century ${ }^{10}$. The crisis of ideas prominent in the second half of the XIX century ${ }^{11}$, the new views of the theorists of Romanticism and the non-stable political situation in Europe before the First World War prepared the necessary ambience for the development of new educational approaches. The political and social crisis in the XIX century Spain, including the low level of literacy in population ${ }^{12}$, conditioned not only the formation of intellectuals as a form of social response, but the vivid polemic on the role of education in the creation and the development of the nation. The Generation of the 1898 played an important role in the developing of modern society ${ }^{13}$. And one of the

Adelina Arredondo \& Antonio Padilla, "John Dewey en México: Una experiencia compartida en el mundo rural," Espacio, Tiempo y Educación 2016, no. 3(2): 33-63.

${ }^{10}$ On this topic: John Boli, Francisco Ramirez, and John Meyer, "Explaining the Origins and Expansion of Mass Education”, Comparative Education Review 29, no. 2 (1985): 145-170; Yasemin Nuhoglu Soysal and David Strang, "Construction of the First Mass Education Systems in NineteenthCentury Europe," Sociology of Education 62, no. 4 (1989): 277-288; Carl Jim, "Industrialization and Public Education: Social Cohesion and Social Stratification", in R. Cowen, Kazamias A.M. (eds), International Handbook of Comparative Education. Springer International Handbooks of Education, vol. 22 (Dordrecht: Springer, 2009); Consuelo Flecha García, "Education in Spain: Close-up of Its History in the 20th Century," Analytical Reports in International Education 4, no. 1 (2011): 17-42; Gabriele Ballarino, Elena Meschi, and Francesco Scervini, "The expansion of education in Europe in the 20th Century”, AIAS, GINI Discussion Paper 83, 2013.

${ }^{11}$ Amable Fernández Sanz, „El problema de España entre dos siglos (XIX-XX)," Anales del Seminario de Historia de la Filosofía 1997, no. 14: 203-222; Patricia Carina Dip, "La crisis de los valores cristianos en el siglo XIX: Kierkegaard y Nietzsche," Universitas Philosophica 2002, no. 38: 191-204; Juan Antonio Cruz Parcero, La crisis de la fundamentación de los derechos humanos en el siglo XIX, La génesis de los derechos humanos en México, 2006.

12 As Felipe B. Pedraza Jiménez and Milagros Rodríguez Cáceres have noted: "De los aproximadamente 10 millones que constituyen la población española en 1800 sólo un 6\%, es decir, unos 600.000 sabían leer" [Felipe B. Pedraza Jiménez, Milagros Rodríguez Cáceres. Manual de literatura española. VI. Época romántica (Pamplona: Cénlit Ediciones, 1982), 64].

${ }^{13}$ An interesting volume was published by the Center of the edition of Spanish classics at the university of Valladolid: Los textos del 98, al cuidado de Juan Carlos Ara y José Carlos Mainer (Valladolid: Centro para la Edición de los Clásicos Españoles, MMII, 2002). 
main educators of Spanish society during this critical moment was Miguel de Unamuno ${ }^{14}$.

John Dewey's views on education played a crucial role in the development of pedagogy in different countries of the world. Writing on the problems of education both in school and university systems, Dewey offered a systematic approach to the topic indicating weak points of the discipline and noting the possible ways of improving the situation. At the same time, professional ethics, academic freedom and philosophical understanding of education were the mainstreams of his thought.

My article is the first attempt to connect Dewey's educational thought to Unamuno's pedagogical doctrine. Despite the fact that at the first glance they represent different cultural ambience and may carry less similar academic features, it seems to me that they are tightly related in understanding education as an instrument for acquiring personal liberty. On the next pages I will try to demonstrate their understanding of main education values in the formation of a free individual.

On the scene of the education Unamuno was acting from double perspective: as an intellectual and as the professional of the field. ${ }^{15}$ Being prominent writer and public figure, Basque philosopher dedicated to the topic both separate essays ${ }^{16}$ and multiple discussions in general texts ${ }^{17}$.

${ }^{14}$ As Unamuno states in his essay Mi religión: "Y lo más de mi labor ha sido siempre inquietar a mis prójimos, removerles el poso del corazón, angustiarlos si puedo. Lo dije ya en mi Vida de Don Quijote y Sancho, que es mi más extensa confesión a este respecto. Que busquen ellos como yo busco, que luchen como lucho yo, y entre todos algún pelo de secreto arrancaremos a Dios, y por lo menos esa lucha nos hará más hombres, hombres de más espíritu" [Miguel de Unamuno, Mi religión, in Mi religión y otros ensayos breves (Madrid: Espasa-Calpe, 1973), 12-13.]

${ }^{15}$ Sobre la enseñanza del clasicismo, in De mi vida (Madrid: Espasa-Calpe, 1979).

${ }^{16}$ Otro arabesco pedagógico, in Los Lunes de "El Imparcial", 22, Diciembre de 1913 [in Obras completas de Miguel de Unamuno (Madrid: Esceliser, 1966), 556]; Mas sobre los pedagogos in La Nación, 12 de septiembre de 1915, pp. 1329 y 1330 [in Obras completas, "Conferencias y discursos", (Madrid: Esceliser, 1970); El día de la infancia, 12 de junio de 1936 [in Obras completas, (Madrid: Esceliser, 1970), 1154].

${ }^{17}$ Paz en la Guerra (Madrid: Editorial Austral, Espasa-Calpe, 1964); Epistolario inédito I (1894- 
As the main characteristics of Unamuno's views on pedagogy and education are already studied, in order to save the space I will not list them here. What I will detect are two main peculiarities of his approach: 1) defining and analysing the methods without forming the concrete system of education, and 2) relating the role of education with an individual's personal liberty.

1) In special literature it is admitted that Unamuno has not formed any system of philosophical thought. Julián Marías in his books "Existencialismo en España"18 and "Miguel de Unamuno"19 noted that despite the fact that Unamuno developed philosophical thought in Spain, he was not a professional philosopher and his legacy is "un grave problema de filosofía". Gómez de la Torre, Morón Arroyo, Joaquín Madruga Méndez and Maroco Santos ${ }^{20}$ agree that Unamuno's essayistic work is of unsystematic nature. The question which we describe here, the education, had the same way of understanding - Unamuno tried to explain his ideas concerning pedagogy in his peculiar manner of polarization of original ideas, enriching them with individual professional experience. His essay titled "Sobre la enseñanza del clasicismo" describes Unamuno's theory in practice. His main professional challenge was to fill the educational process with curiosity, making individuals inquisitive about a new knowledge. According to Unamuno, the main idea of education is to make an individual free and non-dependent on prearranged scholastic schemes. From here comes the necessity of teacher/professor to interface without any defined program of education. The latter makes necessary to rethink the role of teacher in education relating it with the traditional and dogmatic approaches of pedagogy: "Nuestro magisterio no es, no puede ser, dogmático; tiene que ser crítico. Dictar dogmas es engañar al prójimo. Dictar dogmas es matar la libertad de la inteligencia, es matar la inteligencia, porque la

1914), ed. by L. Robles (Madrid: Espasa-Calpe, 1991); Amor y pedagogía (Madrid: Alianza, 1997).

18 Julián Marias, El existencialismo en España (Bogota: Ediciones Universidad Nacional de Colombia, 1953).

${ }^{19}$ Julián Marias, Miguel de Unamuno (Madrid: Espasa Calpe, 1967).

${ }^{20}$ Ignacio Berdugo Gómez de la Torre, "Unamuno y la Universidad: rector e intelectual." in Miguel C. Flórez (coord.), Tu mano es mi destino (Salamanca: Ediciones Universidad de Salamanca, 2000), 47-58; Cirico Morón Arroyo, Hacia el sistema de Unamuno: estudios sobre su pensamiento y creación literaria (Plasencia: Calamo, 2003); Joaquín Madruga Méndez, Miguel de Unamuno: profesor y politico (Salamanca: Gráficas Cervantes, 2007); Emanuel José Maroco Santos, "La Crítica de Unamuno hacia la Pedagogí en cuanto Ciencia Independiente," Educação \& Realidade 43, no. 3 (2018): 1095-1114. 
inteligencia es libertad. Entender es lo único que liberta. La obediencia ciega, propia del esclavo, no es de hombres. ${ }^{21}$

Thus, pedagogy is converted from the profession to the philosophy, less dependent on technical development and aiming the formation of free men:

lo que necesita el maestro es menos pedagogía, mucho menos pedagogía, y más filosofía, mucho más humanidades. El maestro de primeras letras no puede ser, como no puede ser el padre, un especialista. Hacer de la pedagogía una especialidad es perderse en la técnica pura, en la técnica hueca y vana. Y el tecnicismo ha sido, como el positivismo, la plaga intelectual de la segunda mitad del pasado siglo XIX. Y la técnica podrá producir Estados Fuertes, pero no crea pueblos libres y conscientes de su libertad. ${ }^{22}$

2) If the main goal of education is to form free individuals, this must be realized by taking into consideration the role of an individual in the society and his/her basic human rights, as it was outlined in the essay Nacionalismo separatista:

No, eso que llaman el sagrado egoismo colectivo es una de las mayores infamias. Con él se trata de separarnos de la humanidad civil, de la humanidad humana. No, no podemos divorciarnos de pueblos con los que tenemos que convivir y colaborar, y sus problemas son nuestros problemas. Y el supremo problema político es el del Hombre, es el de los Derechos del Hombre. No se puede sacrificar al Hombre ni a un solo hombre, a eso que llaman la salud del pueblo, y que no suele ser salud. Por el principio de "salus populi suprema lex", hicieron los pontíficos y fariseos que se crucificara al Cristo, considerándole antipatriota. ${ }^{23}$

The aim of education according to Unamuno, is to help an individual to find his place in the surrounding world, to realize his/her possibilities. According to this scheme, the person is not the product of the epoch or of the determined borders but of his?her proper possibilities: "hombre universal y eterno, hombre no circunscrito a una época ni a unas fronteras determinadas. El fin del hombre es realizarse". ${ }^{24}$

\footnotetext{
${ }^{21}$ Unamuno, Miguel de, Obras completas VIII (Madrid: Esceliser, 1970), 514.

${ }^{22}$ Ibidem, 1329-1330.

${ }^{23}$ Ibidem, 629.

${ }^{24}$ Múgica, Luis Ross, Más allá del Atlántico (University of California Libraries, 1909), 236.
} 
This was the short summary of Unamuno's views on education. According to him, the main idea of educating individuals is to make them free. And the relation between pedagogy and freedom brings to mind the educational system presented by John Dewey.

1) In his famous Democracy and Education Dewey makes emphasis on the aims in education. After recognizing that "education as such has no aims"25 and offering the term "suggestions to educators" in place of aims $s^{26}$, Dewey lists some main aims a productive educational system may be based on. According to him:

An aim must be capable of translation into a method of cooperating with the activities of those undergoing instruction. It must suggest the kind of environment needed to deliberate and to organize their capacities. Unless it lends itself to the construction of specific procedures, and unless these procedures test, correct, and amplify the aims, the latter is worthless. Instead of helping the specific task of teaching, it prevents the use of ordinary judgment in observing and sizing up the situation. It operates to exclude recognition of everything except what squares up with the fixed end in view. ${ }^{27}$

Here we see the intention to understand the aim of education as the method of cooperation between a teacher and an individual to be educated. Emphasis is made here on the discovering of one's capacities based on the construction of procedures which in turn test the aims. This is the critical approach to education which was considered by Unamuno as anti-dogmatic and of humanistic nature. ${ }^{28}$ By this we observe the educational system oriented on the individual, helping him to recognize personal possibilities that will make him free. Dewey insists that "The sole direct path to enduring improvement in the methods of instruction and learning consists in centering upon the conditions which exact, promote,

${ }^{25}$ John Dewey, Education as necessity, in Democracy and Education. The Middle Works 18991924, vol. 9, (Carbondale: Southern Illinois University Press, 1916), 114.

${ }^{26}$ Ibidem.

${ }^{27}$ Ibidem, 115.

${ }^{28}$ Unamuno, Obras completas VIII, 514. 
and test thinking. Thinking is the method of intelligent learning, of learning that employs and rewards mind“ ${ }^{29}$ Critical approach helps to develop the possibility of start thinking, thus converting intelligent activity into method. This is the first educational link between Unamuno and Dewey.

2) Continuing the discussion, Dewey characterizes the role of educators as protectors against the generalization of ideas which may be easily transformed into abstractness, in other words, which may be detached from concrete context:

Educators have to be on their guard against ends that are alleged to be general and ultimate. Every activity, however specific, is, of course, general in its ramified connections, for it leads out indefinitely into other things. So far as a general idea makes us more alive to these connections, it cannot be too general. But "general" also means "abstract", or detached from all specific context. And such abstractness means remoteness, and throws us back, once more, upon teaching and learning as mere means of getting ready for an end disconnected from the means. That education is literally and all the time its own reward means that no alleged study or discipline is educative unless it is worthwhile in its own immediate having. A truly general aim broadens the outlook; it stimulates one to take more consequences (connections) into account. This means a wider and more flexible observation of means. ${ }^{30}$

According to Dewey, both teaching and learning may not be mere means, rather they should have own and immediate products. Thus, teaching is not the empty technics which forms from pedagogy the specialty as the specialty cannot create free nations which may be aware of their freedom. ${ }^{31}$ Dewey recognizes that "An individual must actually try, in play or work, to do something with material in carrying out his own impulsive activity, and then note the interaction of his energy and that of the material employed". ${ }^{2}$ Thus pedagogy is not a form of technology, it is a way of mental creation and recreation which considers education as instrument for understanding the surrounded world. This is the second link between Unamuno and Dewey.

3) The only theories which may be useful in education may be the sort of personal theories, generated and tested individually. Self-understanding is

\footnotetext{
${ }^{29}$ Dewey, "Education as necessity", 159.

${ }^{30}$ Ibidem, 116.

${ }^{31}$ Unamuno, Obras completas VIII, 1329-1330.

${ }^{32}$ Dewey, "Education as necessity," 160.
} 
the only way of escaping from dogmas and looking for, or trying to, understand the truth. As Dewey put it, "Men must observe for themselves, and form their own theories and personally test them. Such a method was the only alternative to the imposition of dogma as truth, a procedure which reduced mind to the formal act of acquiescing in truth". ${ }^{33}$ Unamuno's approach to truth is the same: questioning is the only way for understanding:

Y como el hombre es terco y no suele querer enterarse y acostumbra después que se le ha sermoneado cuatro horas volver a las andadas, los preguntones, si leen esto, volverán a preguntarme: "Bueno, pero ¿qué soluciones traes?” Y yo, para concluir, les diré que si quieren soluciones, acudan a la tienda de enfrente, porque en la mía no se vende semejante artículo. Mi empeño ha sido, es y sera que los que me lean, piensen y mediten en las cosas fundamentales, y no ha sido nunca el de darles pensamientos hechos. Yo he buscado siempre agitar y a lo sumo sugerir más que instruir. Si yo vendo pan, no es pan, sino levadura o fermento. ${ }^{34}$

Unamuno and Dewey coincide in the will to help the individual develop personal skills, to ask questions in order to approximate himself/herself to the metaphysical truth. The main idea of education, thus, seems to be the developing of personality, learning by questioning, ignoring dogmas and the apparent reality which rests on the surface of the common things. In this case the role of mind is decisive and the critical approach to education and self-understanding is achieved. This is the third link between Unamuno and Dewey.

In the last part of my article I will try to perform some final reflection on the similarity of educational approaches proposed by John Dewey and Miguel de Unamuno. What is apparent for me is the relation between education and individual approaches on the one hand, and, as the result of the mentioned, the formation of free individual as the main goal of education.

${ }^{33}$ Ibidem, 303.

${ }^{34}$ Unamuno Miguel de, Mi religión, in Mi religión y otros ensayos breves (Madrid: Espasa-Calpe, 1973), 14. 
To be more illustrative, I will summarize Dewey's and Unamuno's ideas as an unique educational system, which carries the main goal of individual liberation through education. There is no doubt that the accumulation of knowledge results in deeper understanding of proper possibilities. The latter is an instrument for discovering the truth which can help an individual to create and share the values in society. Dewey noted that "It is no accident that the terms communication and community lie so near together; or that intercourse means equally speech and any intimate mode of associated life. ${ }^{35}$ As Unamuno put it, discovering truth is the equivalent of rejecting dogmas, of trying to reach with proper mental possibilities the answers to main questions of existence. This is the way of understanding the life which makes a man free. Mental operation, and not the technical progress, is the instrument for self-recognition. That is why the role of individual is prominent and decisive and each citizen is equally important for society. To the mentioned, Dewey adds the importance of special ambience which will help individual to reveal and develop personal skills. And Unamuno's questioning is the same phenomena as Dewey's thinking, as the "method of intelligent learning". The role of teacher, thus, is to stimulate thinking, not to drown into pedagogical schemes and pure technical approaches (Unamuno) and not to draw the ends of general and ultimate nature (Dewey).

Miguel de Unamuno's and John Dewey's educational approaches should be considered as the reflection based on the development of their contemporary educational system. Naturally, after almost a century, these opinions need to be adjusted to our contemporary views of pedagogy and the building of civic society. However, what makes their ideas vivid and still progressive is the method of placing the individual in the centre of pedagogical process, arming him with the education as the main instrument to protect against the society.

\section{Bibliography}

Aguilera, Cesar. "Pensamiento educacional de D. Miguel de Unamuno." Calasencia 11, no. 44 (1965): 405-523.

Alberto Torres, Carlos. “Democracia y Educación: John Dewey y Paulo Freire.” Cuestiones Pedagógicas 2014, no. 23: 29-42.

${ }^{35}$ Dewey John, The Problem of Truth, in Democracy and Education. The Middle Works (18991924, 9, 1978), 16. 
Barros Dias, José Manuel de. "Miguel de Unamuno: a teorização da educação contra a modernidade da Pedagogia." Broteria. Cultura e Informação 139, no. 2-3 (1994): 167181.

Berdugo Gómez, Ignacio. “Unamuno y la universidad: rector e intellectual.” In Tu mano es mi destino, coord. Miguel C. Flórez, 21-28. Salamanca: Ediciones Universidad de Salamanca, 2000.

Blanco Prieto, Francisco. Unamuno: profesor y rector en la Universidad de Salamanca. Salamanca: Hergar Ediciones Antema, 2011.

Cadrecha Caparros, Miguel Ángel. "John Dewey: propuesta de un modelo educativo: I. Fundamentos." Aula Abierta 1990, no. 55: 61-87.

Carreras Planas, C. "John Dewey i l'educaciy democratica," Educaciy i Histrria: Revista d'Histrria de l'Educaciy 2015, no. 25: 21-42.

Catalán, Miguel, “John Dewey: Los límites de la ética científica”, Agora 1994, no. 13/1: 139147.

Catalán, Miguel, "Una presentación de John Dewey." Daimon. Revista de Filosofía 2001, no. 2: 127-134.

Cláudio Matos, José. “John Dewey e Aldous Huxley: o admirável e o impensável na formação social da mentalidade," Conjectura Caxias do Sul 16, no. 3 (2011): 78-96.

Delgado Criado, Buenaventura, Unamuno educador. Madrid, Editorial Magisterio Español, 1973.

Dewey, John, "Education as necessity." In Democracy and Education, The Middle Works 1899. 1924, vol. 9, 4-13. (Carbondale: Southern Illinois University Press), 1916.

Dewey, John, “The Problem of Truth”. In Democracy and Education, The Middle Works 18991924, vol. 9, 12-68. (Carbondale: Southern Illinois University Press), 1978.

Esteban Cloquell, José Miguel, “John Dewey y la tragedia de los communes”, Éndoxa: Series Filosóficas 2017, no. 39: 265-284.

Fenyő, Imre, “The Reception of John Dewey in Hungary”, Espacio, Tiempo y Educación 2016, no. 3(2): 183-205.

Fermoso Estébanez, Paciano, “Bibliografía sobre John Dewey: Filosofía de la Educación”, Teoría de la Educación 1991, no. 3: 165-178.

Fernandes de Andrade, Erika Natacha \& Marcus Vinicius da Cunha. “A contribuição de John Dewey ao ensino da arte no Brasil”, Espacio, Tiempo y Educación 2016, nr 3(2): 301-319.

García Blanco, Manuel. "Don Miguel y la Universidad”, Cuadernos de la Cátedra Miguel de Unamuno 1963, no. 13: 13-32.

Gómez Molleda, María. “Unamuno y la polémica sobre la autonomía universitaria.” In AA. VV. Perspectivas de España Contemporánea. Estudios en homenaje al professor V. Palacios Atard, 355-369. Madrid: Guthersa, 1986.

Gómez de la Torre, Ignacio Berdugo. "Unamuno y la Universidad: rector e intelectual." In Flórez Miguel, C. (coord.), Tu mano es mi destino, 47-58. Salamanca: Ediciones Universidad de Salamanca, 2000. 
González Hernández, David, "El público y sus problemas. John Dewey en los estudios de comunicación,” Razón y Palabra 2011, no. 75: 1-14.

Gordo Piñar, Gemma. "El pensamiento educativo de Miguel de Unamuno”, Humanistyka i Przyrodoznawstwo 2012, no. 18: 167-182.

Herrero Castro, César Aguillera. "Pensamiento social-educativo de Miguel de Unamuno: estructura y cambio social en la Españ del primer tercio del siglo XX," Studia Paedagogia 1991, nr 22: 55-79.

Kennedy, David, "John Dewey on children, childhood, and education," Childhood \& Philosophy2, no. 4, 2006: 211-229.

Madruga Méndez, Joaquín. Miguel de Unamuno: profesor y politico. Salamanca: Gráficas Cervantes, 2007.

María Rosales, José. "La retórica de la democracia y el liberalismo político en los escritos de John Dewey," Revista de Estudios Políticos 2012, no. 155: 185-206.

Maroco Santos, Emanuel José. "La Crítica de Unamuno hacia la Pedagogí en cuanto Ciencia Independiente," Educação \& Realidade 43, no. 3 (2018): 1095-1114.

Miovska-Spaseva, Suzana, "The educational theory of John Dewey and its influence on educational policy and practice in Macedonia," Espacio, Tiempo y Educación 2016, no. 3(2): 207-224.

Morón Arroyo, Cirico, Hacia el sistema de Unamuno: estudios sobre su pensamiento y creación literaria, Plasencia: Calamo, 2003.

Múgica, Luis Ross, Más allá del Atlántico, University of California Libraries, 1909.

Pallarès Piquer, Marc \& María Carmen Muñoz Escalada. "La vigencia de Hannah Arendt y John Dewey en la acción docente del siglo XXI,” Foro de Educación 2017, no. 15(22): 1-23.

Pedraza Jiménez, Felipe y Milagros Rodríguez Cáceres. Manual de literatura española. VI. Época romántica, Pamplona: Cénlit Ediciones, 1982.

Rogacheva, Yelena. “The Reception of John Dewey's Democratic Concept of School in Different Countries of the World," Espacio, Tiempo y Educación 2016, no. 3(2): 65-87.

Rubin, Richard Marc. "George Santayana and John Dewey meet," Limbo 2010, no. 30: 31-52.

Rubio Latorre, Rafael. Educación y educador en el pensamiento de Unamuno, Salamanca: Ediciones Instituto Pontífico San Pio X, 1974.

Santos Gómez, Marcos, “Limitaciones de la pedagogía de John Dewey,” Bordón 2011, no. 63 (3): $121-130$.

Skowroński Krzysztof. "Entre política y estética: la idea de la democracia liberal en la filosofía del arte de John Dewey," La torre del Virrey, Revista de Estudios Culturales, no. 19 (2016): $1-11$.

Sotelino Losada, Alexandre. “A aprendizaxe-servizo en perspectiva. John Dewey como referente histórico," Sarmiento 2015, no. 18-19: 145-162.

Taylor Xóchil Arredondo, Adelina \& Antonio Padilla. "John Dewey en México: Una experiencia compartida en el mundo rural,” Espacio, Tiempo y Educación 2016, n0. 3(2): 33-63.

Unamuno, Miguel de. Obras completas VIII. Madrid: Esceliser, 1970. 
Unamuno, Miguel de. Mi religión. In Mi religión y otros ensayos breves. Madrid: Espasa-Calpe, 1973.

Vaamonde Gamo, Marta \& Jaime Nubiola. "El legado feminista de John Dewey," Espacio, Tiempo y Educación 2016, no. 3(2): 281-300.

Zorić, Vucina. "Influencia de John Dewey en las reformas educativas en Turquía y en la Unión Soviética," Espacio, Tiempo y Educación 2016, no. 3(2): 101-130.

Streszczenie

Miguel de Unamuno i John Dewey: system edukacji a osobowa wolność

Artykuł stanowi interpretację poglądów na edukację sformułowanych przez Miguela de Unamuno i Johna Deweya i składa się z trzech części. Po krótkim wprowadzeniu, opisującym ogólne poglądy Unamuno i Deweya na edukację oraz ich wpływ na rozwój systemu edukacji $\mathrm{w}$ różnych krajach, w pierwszej części artykułu przedstawiam przyczynek Unamuno do edukacji jako takiej oraz w szczególności rolę pedagogiki. W drugiej części interpretuję edukację na podstawie perspektywy Deweya. Część trzecia stanowi analizę podobieństw w rozumieniu roli edukacji oraz jej miejsce w formowaniu osobowej wolności. Artykuł jest pierwszą próbą połączenia poglądów Unamuno i Deweya w kontekście tego tematu.

Słowa kluczowe: Miguel de Unamuno, John Dewey, edukacja, osobowa wolność 


\author{
Zusammenfassung \\ Miguel de Unamuno und John Dewey: \\ das Bildungssystem und die persönliche Freiheit
}

\begin{abstract}
Der Artikel legt die von Miguel de Unamuno und John Dewey formulierten Bildungsanschauungen aus und besteht aus drei Teilen. Nach kurzer Einführung, die allgemeine Anschauungen der beiden Philosophen und ihren Einfluss auf die Entwicklung des Bildungssystems in unterschiedlichen Ländern beschreibt, schildere ich Unamunos Beitrag zur Bildung als solcher mit besonderer Berücksichtigung der Rolle der Pädagogik. Im zweiten Teil interpretiere ich die Bildung auf der Grundlage der Perspektive von Dewey. Im dritten Teil werden Ähnlichkeiten im Verständnis der Rolle der Bildung und ihrer Stellung in der Ausbildung der persönlichen Freiheit analysiert. Der Beitrag ist der erste Versuch, die Anschauungen von Unamuno und Dewey in diesem Kontext zu vereinigen.
\end{abstract}

Schlüsselworte: Miguel de Unamuno, John Dewey, Bildung, persönliche Freiheit

Informacje o Autorze:

VLADIMER LUARSABISHVILI, doktor, Group of investigation CPyR (UAM), profesor na Wydziale Polityki i Stosunków Międzynarodowych w New Vision University, Tbilisi; adres do korespondencji: New Vision University, 1a Evgeni Mikeladze St., 0159, Tbilisi, Georgia; e-mail: vluarsabishvili@newvision.ge

(c) BY-NC-ND 